\title{
Proposed Bylaws of the College Libraries Section of ACRL
}

\section{Article I. Name}

The name of this organization is the College Libraries Section of the Association of College and Research Libraries of the American Library Association.

Article II. Object

The object of the Section shall be to advance college librarianship, college library service, and the development of college libraries.

\section{Article III. Membership}

Any member of the Association of College and Research Libraries may elect membership in this Section.

\section{Article IV. Officers}

The officers of the Section shall be a chairman, a vice-chairman who is chairman-elect, the immediate past chairman, and a secretary. The chairman shall serve for one year. The chairman-elect shall serve for one year as vice-chairman at the expiration of which term, or upon the occurrence of an earlier vacancy in the office of chairman, he shall succeed to the office of chairman. The immediate past chairman serves for one year as an officer and the secretary serves for one year.

\section{Article V. Executive Board}

Sec. 1. Composition. The Executive Board shall consist of five members: The chairman, the secretary, the incoming chairman, the immediate past chairman, and the past secretary. The Executive Secretary of the Association of College and Research Libraries shall be an ex-officio member.

Sec. 2. Meetings. Regular meetings of the Executive Board are to be held at times and places of the annual and midwinter meetings of the American Library Association. Special meetings may be called at the discretion of the chairman. All regular meetings of the Board shall be open to all members of the Section.

Sec. 3. Powers and duties. The main function of the Executive Board shall be to provide direction for the Section. The board has authority over the affairs of the Section during the period between meetings of the Section, subject to review by the members at a meeting of the Section.

Sec. 4. Quorum. A majority of members constitutes a quorum at any meeting of the Executive Board.

\section{Article VI. Committees}

Sec. 1. Authorization. Committees of the Sec- tion shall be established by action of the chairman after consultation with the Executive Board.

Sec. 2. Standing Committees. Standing committees may be established to consider matters of the Section that require continuity of attention by the members. When such a committee is established its function, name, and size shall be determined. Unless otherwise approved by the Executive Board, members of standing committees shall be appointed for terms of two years and may be reappointed for a second and third but not a fourth consecutive term; in no case shall a person serve on a committee for more than six consecutive years. Appointments shall be made in such a manner as to provide continuity in membership.

Sec. 3. Special Committees. Special committees ( ad hoc) may be established at any time by the chairman, with the approval of the Executive Board, for the performance of a particular assignment. No such committee may be continued beyond two years without review and reapproval by the Executive Board.

Sec. 4. Appointment. The vice-chairman (chairman-elect) of the Section shall appoint committee members to fill the vacancies due to occur during his term as chairman; he may name the chairman of each committee or request the committee to elect its own chairman. Special appointments to fill vacancies on committees may be made by the chairman of the committee.

Sec. 5. Discontinuance. A committee may be dissolved by the chairman of the Section with the approval of the Executive Board.

\section{Article VII. Nominations and Elections}

Sec. 1. Nominating Committee. The vice-chairman (chairman-elect) of the Section shall appoint a Nominating Committee of at least three members, designating one of the members as committee chairman. This committee shall choose, in accordance with the time schedule set by the Executive Secretary of the Association of College and Research Libraries, a slate of two nominees for each of the offices of chairman-elect and secretary. All nominees must be members of the Section and no candidate shall be presented who has not consented in writing to his candidacy.

Sec. 2. Statement of objectives. To permit the membership of the Section to have an informational basis for voting each candidate for the office of chairman-elect shall be asked to provide a brief statement of his objectives for the Section 
in time for the statement to be published prior to balloting.

Sec. 3. Additional nominees. Additional nominations for inclusion on the ballot may be made by petitions signed by no fewer than twenty members of the Section and filed with the Executive Secretary of the Association of College and Research Libraries at least three months prior to the annual conference of the American Library Association. No person may be nominated who is not a member of the Section and the petition must be accompanied by the written consent of the nominee to stand for election. If the nomination is for the office of chairman-elect a statement of objectives should also be submitted.

Sec. 4. Election. Elections shall be conducted by mail ballot and the candidate receiving the largest number of votes shall be deemed elected. Results of the election shall be made public at the annual conference of the American Library Association.

\section{Article VIII. Vacancies}

When the office of the chairman or of the secretary is vacated it shall be filled by the chairman-elect or secretary-elect, and the latter shall continue in office through his original elected term. Should both the chairman and chairmanelect, or the secretary and secretary-elect, vacate their offices in the same year the Executive Board shall meet to choose a member of the Board to serve as acting chairman and/or secretary until the next regular election for the office is held.

\section{Article IX. Meetings}

The regular meeting of the Section shall be held at the time and place of the annual conference of the American Library Association. Special meetings may be called by the chairman with the approval of the Executive Board. The Section may, with the approval of the Board of Directors of the Association of College and Research Libraries, hold closed meetings or joint meetings with other sections.

\section{Article X. Amendments}

Sec. 1. Proposals. Amendments to the bylaws may be proposed by any committee of the Section or by petition signed by twenty members of the Section. Proposed amendments shall be presented in writing to the chairman.

Sec. 2. Voting. The bylaws may be amended either by a mail vote approved by two-thirds of the members voting or by a two-thirds vote of the members present and voting at any given meeting of the Section.

NOTE: The proposed Bylaws of the College Libraries Section have been approved by the Board of Directors and will be presented for final approval at the CLS membership meeting at the annual conference in Las Vegas.

\begin{tabular}{|c|c|c|c|}
\hline Unit & $\begin{array}{c}\text { Personal } \\
\text { Membership } \\
\text { as of } \\
\text { December } \\
31,1971\end{array}$ & $\begin{array}{c}\text { Personal } \\
\text { Membership } \\
\text { as of } \\
\text { December } \\
31,1972\end{array}$ & $\begin{array}{l}\text { Approved } \\
\text { Budgets } \\
\text { for ALA } \\
\text { Divisions } \\
1972-73^{\circ}\end{array}$ \\
\hline American Library Association & 25,984 & 26,159 & \\
\hline American Association of School Libraries & 9,371 & 9,241 & $\$ 91,699$ \\
\hline American Library Trustee Association & 3,582 & 3,660 & 23,397 \\
\hline Association of College and Research Libraries & 12,101 & 12,472 & 65,360 \\
\hline Association of Hospital and Institution Libraries & 1,718 & 1,778 & 35,221 \\
\hline Association of State Library Agencies & 1,290 & 1,366 & 20,802 \\
\hline Children's Services Division & 6,603 & 6,582 & 27,899 \\
\hline Information Science and Automation Division & 4,750 & 4,632 & 26,926 \\
\hline Library Administration Division & 5,293 & 5,264 & 66,031 \\
\hline Library Education Division & 2,665 & 2,654 & 33,526 \\
\hline Public Library Association & 9,144 & 9,170 & 23,690 \\
\hline Reference and Adult Services Division & & 9,219 & 58,841 \\
\hline Adult Services Division & 3,070 & & \\
\hline Reference Services Division & 7,214 & & \\
\hline Resources and Technical Services Division & 9,080 & 9,069 & 54,955 \\
\hline Young Adult Services Division & 7,106 & 7,076 & 26,645 \\
\hline Budgets for $1973-74$ are under preparation. & & & \\
\hline
\end{tabular}




\section{MISSING ISSUES}

\section{CAUSING YOU}

PROBLEMS?

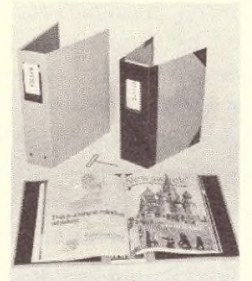

Check into TEMPLOK ${ }^{\text {TM }}$

Storage Binders

"The Reuseables"

for as little

as $\$ 4.26$ each

Write to:

Systematic Storage Co., Inc.

223 East Douglas

Bloomington, Illinois

61701

\section{Now Available \\ LC SUBJECT HEADINGS SUPPLEMENTS \\ 1966-1971 CUMULATION}

A new tool to cut the time and complexity of subject cataloging.

Produced from the unedited Library of Congress magnetic tape source files of annual supplement data for

1966 through 1971. (The $1964 / 65$ supplement is not accessible in machine readable form. )

Edited to ensure conformity with the LC Printed Supplements.

Eliminates the need to check six annual supplements to the LC 7th Edition.

Format of the cumulated supplements is similar to standard LC Printed Supplement style. Variations from LC display are explained in full.

Convenient $8 \frac{1}{2} \times 11^{\prime \prime}$ size. 793 pages.

Free descriptive brochure avajlable on request.

Price. $\$ 40.00$ ppd

DIRECTOR, UNIVERSITY-WIDE

LIBRARY AUTOMATION PROGRAMS INSTITUTE OF LIBRARY RESEARCH

SOUTH HALL ANNEX, BOX R

UNIVERSITY OF CALIFORNIA

BERKELEY, CALIFORNIA 94720
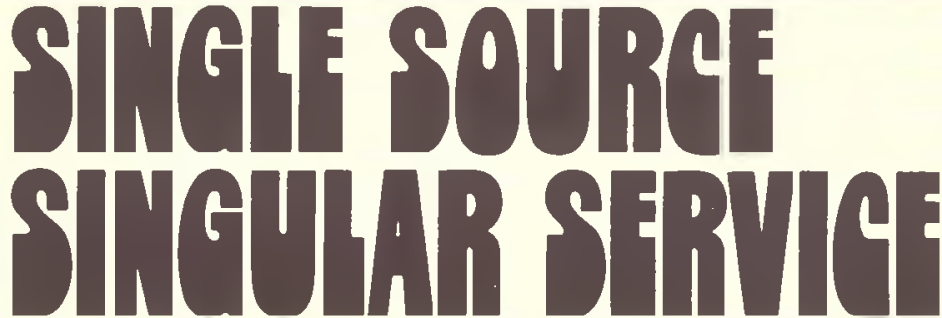

AlL desired titles, periodicals and irregulars, foreign or domestic, available from one source... simplifies your work. Regional offices assure exceptional, decentralized service. Next time, give us a call . . . we'd like to be of service.

\section{EBSCO SUBSCRIPTION SERVICES}

826 S. Northwest Highway

Barrington, III. 60010

(312) 381-2190

P. O. Bex 1943

Bimingham, Ala. 35201

(205) 071.3529

540 Granite Streep

Braintree, Mass. 02184

(617) 843-2303

415 Douglas Plaza Bullding

Dallos, Texes 75225

(214) 369-7591
Sulf 110-s, Diamend Hill Complex

2480 W. 26th Avenue

Denver, Colo. 80211

(303) 433.3235

2352 Utah Avenue

EI Segundo, Calif, 90245

(213) $772-2381$

512 Nicollet Building

Minneapolis, Minn, 35402

(612) 333-50e1

Easco Building

Red Dank, N.J. 07701

(201) $741-4300$
681 Market Streel

Sen Franciseo, Calif. 94105 (415) $391-3500$

5406-A Port Royal Rd.-Sulte 200 Springfield, Va, 22151

(703) 321-7516/321-9630

545 Cedor tane

Teaneck, N.J. 07666

(201) 836.8700

Slx Thomeliff Park Dive

Torente 17, Onforle, Conedo

(416) 421-9000

$$
\text { Easce }
$$

Easco 


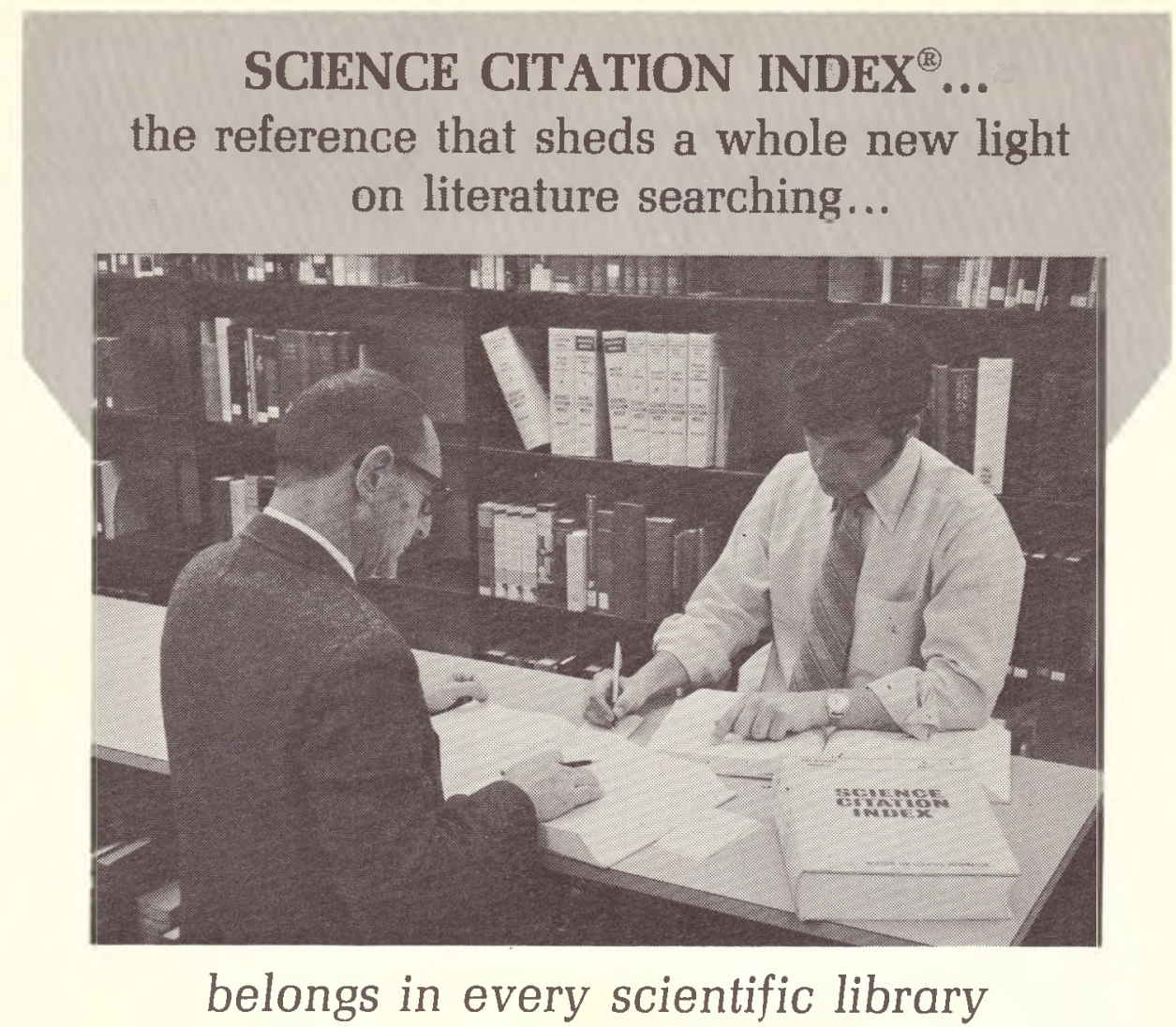

Science Gitation Index - the uniquely effective search tool that organizes the world's current scientific journal literature by the authors' own reference citations - retrieves more pertinent articles on almost any given subject, faster, than any other reference of any kind.

It's the one multi-disciplinary retrospective search tool that serves all departments because it covers all scientific subjects with unmatched authority. It's the one reference that finds material that gets lost in the limitations of conventional, subjectoriented literature indexing systems.

SCI ${ }^{\circledR}$ makes use of an indexing system that follows scientists' own traditional method of literature searching - that of locating articles related to their subject interests by examining reference citations of articles known to be relevant. The technique is called "citation indexing". And the SCI is the only comprehensive index to the journal literature that offers it.

The Science Citation Index is the one standard literature-search reference that no library serving the scientific community can afford to be without. If your library doesn't yet have this most useful of all literature retrieval tools... used by libraries large and small ... bring your search capabilities up to date now. And plan extra sets for branch and departmental libraries where they can do the most good for your entire organization. (Special matching grants are available to smaller departmental and branch libraries to make it economical to obtain multiple sets of SCI.)

For more on what the Science Citation Index can do for your library, send for our new brochure. 